\title{
Effects of Fire and Commercial Thinning on Future Habitat of the Northern Spotted Owl
}

\author{
Dennis C. Odion ${ }^{1, *}$, Chad T. Hanson ${ }^{2}$, Dominick. A. DellaSala ${ }^{3}$, William L. Baker ${ }^{4}$ and Monica L. \\ Bond $^{5}$
}

${ }^{I}$ Earth Research Institute, University of California, Santa Barbara, California. 93106. Environmental Studies Department, Southern Oregon University, Ashland, Oregon, 97520

${ }^{2}$ Earth Island Institute, 2150 Allston Way, Suite \#460, Berkeley, California, 94704

${ }^{3}$ Geos Institute, Ashland, Oregon, 97520

${ }^{4}$ Program in Ecology and Department of Geography, University of Wyoming, Laramie, WY, 80271

${ }^{5}$ Wild Nature Institute, PO Box 165, Hanover, NH 03755

\begin{abstract}
The Northern Spotted Owl (Strix occidentalis caurina) is an emblematic, threatened raptor associated with dense, late-successional forests in the Pacific Northwest, USA. Concerns over high-severity fire and reduced timber harvesting have led to programs to commercially thin forests, and this may occur within habitat designated as "critical" for spotted owls. However, thinning is only allowed under the U.S. Government spotted owl guidelines if the long-term benefits clearly outweigh adverse impacts. This possibility remains uncertain. Adverse impacts from commercial thinning may be caused by removal of key habitat elements and creation of forests that are more open than those likely to be occupied by spotted owls. Benefits of thinning may accrue through reduction in high-severity fire, yet whether the firereduction benefits accrue faster than the adverse impacts of reduced late-successional habitat from thinning remains an untested hypothesis. We found that rotations of severe fire (the time required for high-severity fire to burn an area equal to the area of interest once) in spotted owl habitat since 1996, the earliest date we could use, were 362 and 913 years for the two regions of interest: the Klamath and dry Cascades. Using empirical data, we calculated the future amount of spotted owl habitat that may be maintained with these rates of high-severity fire and ongoing forest regrowth rates with and without commercial thinning. Over 40 years, habitat loss would be far greater than with no thinning because, under a "best case" scenario, thinning reduced 3.4 and 6.0 times more dense, late-successional forest than it prevented from burning in high-severity fire in the Klamath and dry Cascades, respectively. Even if rates of fire increase substantially, the requirement that the long-term benefits of commercial thinning clearly outweigh adverse impacts is not attainable with commercial thinning in spotted owl habitat. It is also becoming increasingly recognized that exclusion of high-severity fire may not benefit spotted owls in areas where owls evolved with reoccurring fires in the landscape.
\end{abstract}

Keywords: Fire rotation, forest regrowth rate, forest thinning, future habitat, habitat loss, late-successional forest, policy implications, severe fire, spotted owl.

\section{INTRODUCTION}

Conservation of the emblematic Northern Spotted Owl (Strix occidentalis ssp. caurina) in the Pacific Northwest of North America has become a global example of balancing conflicting land management goals (DellaSala and Williams 2006). Concern over degradation of the owl's dense, latesuccessional forest habitat led to the 1994 Northwest Forest Plan (NWFP). The NWFP shifted management on $\sim 100,000$ $\mathrm{km}^{2}$ of federal USA forestlands from an emphasis on resource extraction to embrace ecosystem management and

*Address correspondence to this author at the Earth Research Institute, University of California, Santa Barbara, California. 93106. Environmental Studies Department, Southern Oregon University, Ashland, Oregon, 97520; Tel/Fax: 541 821-0738; E-mail: dennis@ odion.name biodiversity conservation goals. Under the NWFP, 30\% of federal lands traditionally managed for timber production were placed in late-successional reserves that emphasized conservation goals and limited timber harvesting (USFS/USDI 1994).

Over the last decade, managers and policy makers have become increasingly concerned about high-severity fire and reduced timber harvesting in NWFP dry forests (e.g., Spies et al. 2006, Power 2006, Thomas et al. 2006, Ager et al. 2007, USFWS 2011). Forest thinning has been viewed as a solution for controlling fires in dry forests throughout western North America (Agee and Skinner 2005, Stephens and Ruth 2005) and commercial criteria have been included to pursue timber harvest goals (Johnson and Franklin 2009, Franklin and Johnson 2012). Commercial thinning prescriptions currently being implemented under these 
criteria may remove up to one-half of forest basal area, and may also include patch cutting or small clear cuts (USDI 2011). Commercial thinning is now proceeding rapidly without a full understanding of the long-term risks.

For spotted owls, thinning and associated activities often remove or reduce key habitat features in direct proportion to the intensity of the commercial prescription. Key spotted owl habitat features that may be reduced or removed directly or indirectly include high tree density and canopy cover (King 1993, Pidgeon 1995), recently killed pines (Pinus spp.) and abundant snags (Pidgeon 1995), multiple tree layers, with abundant medium and small white fir (Abies concolor) or Douglas-fir (Pseudotsuga menziesii) (King 1993, Pidgeon 1995, Everett et al. 1997, Irwin et al. 2012), large volume of mature-sized down logs (Pidgeon 1995), shrubs (King 1993, Pidgeon 1995, Irwin et al. 2012) and trees with heavy mistletoe infections (Hessburg et al. 2008), which are essential for spotted owl nesting (USFWS 2011). Thinning or contemporary harvest near the nest or activity center has been shown to displace Northern Spotted Owls (Forsman et al. 1984, King 1993, Hicks et al. 1999, Meiman et al. 2003). Telemetry studies on California Spotted Owls (Strix occidentalis ssp. occidentalis) in the Sierra Nevada found that owls avoided Defensible Fuel Profile Zones (an intensive thinning treatment) (USFS 2010). Unoccupied California Spotted Owl territories had a lower probability of re-occupancy after timber harvest, even when habitat alterations comprised $<5 \%$ of a territory (Seamans and Gutiérrez 2007). In addition, Barred Owls (S. varia), which out-compete spotted owls (Dugger et al. 2011), use younger and more open forests compared to Northern Spotted Owls (Wiens 2012).

Studies also have found negative impacts of thinning to northern flying squirrels (Glaucomys sabrinus), the primary prey of Northern Spotted Owls in most of its range (Waters and Zabel 1995, Waters et al. 2000, Carey 2001, Ransome and Sullivan 2002, Gomez et al. 2005, Ransome et al. 2004, Bull et al. 2004, Meyer et al. 2007, Wilson 2008, Holloway and Smith 2011, Manning et al. 2012). Negative effects may persist for 15 years or longer (Wilson 2008). In addition, openings between trees from thinning may create barriers, due to predator avoidance, for flying squirrels to cross using its gliding locomotion (Manning et al. 2012). Thinning has also been found to have negative effects on the abundance of other main prey species for Northern Spotted Owls such as red-backed voles (Myodes californicus) (Suzuki and Hayes 2003) and woodrats (Neotoma cinerea, $N$. fuscipes) (Lehmkuhl et al. 2006).

Because of the many conflicts between thinning and spotted owl conservation, some authors have recommended that treatments aimed at controlling fire avoid spotted owl habitat and instead treat vegetation elsewhere that is the most flammable and strategic for accomplishing fuel treatment goals (Gaines et al. 2010). The 2011 Recovery Plan for the Northern Spotted Owl, the blueprint for management of this species on federal lands in the region (USFWS 2011), contains the proviso that long-term benefits to spotted owls of forest thinning treatments must clearly outweigh adverse impacts (USFWS 2011). The U.S. Fish and Wildlife agency that developed the plan suggested that benefits over time might accrue from a net increase in habitat because fire disturbances would be reduced (USFWS 2011). But whether the benefits would outweigh the impacts remains uncertain due to limitations of previous assessments.

Previous assessments of the efficacy of thinning treatments in reducing fire disturbances in spotted owl habitat (Wilson and Baker 1998, Lee and Irwin 2005, Roloff et al. 2005, 2012, Calkin et al. 2005, Hummel and Calkin 2005, Ager et al. 2007, Lehmkuhl et al. 2007) have not incorporated the probability of high-severity fires occurring during the treatment lifespan. The effect of this is to overestimate treatment efficacy in potentially controlling fire or fire behavior (Rhodes and Baker 2008). Nor have the effects of recruitment of dense, late-successional forest that act to offset loss from fire been included in prior assessments. In addition, impacts of the kind of commercial thinning treatments being implemented to address dry forest concerns have not been fully considered for the owl or its prey (e.g., Ager et al. 2007, Lehmkuhl et al. 2007, Roloff et al. 2012). Current commercial thinning prescriptions being implemented in dry forests specifically identify desired future conditions to be maintained (e.g. Johnson and Franklin 2009) that have basal area and other structural targets mostly well below the minimum levels that have been found in spotted owl nesting, roosting and foraging habitat (NRF) in dry forests. For example, basal area targets in a project in southwest Oregon designed to demonstrate the thinning prescriptions in dry forest spotted owl habitat were $13.75-27.5 \mathrm{~m}^{2} /$ ha (USDI 2011), while stands $<23 \mathrm{~m}^{2} /$ ha very rarely support spotted owl nesting territories (Buchanan and Irwin 1995). In addition, the Recovery Plan (USFWS 2011) permits thinning in core areas, but emphasizes treating areas outside of core areas, so there is a need for assessment of impacts outside core areas as well. Areas outside cores may be essential for foraging and be part of the breeding season home range. Furthermore, owls often move outside core areas (USFWS 2011). Lastly, available habitat outside existing cores may become important to owl recovery, particularly if spotted owls are displaced from higher quality habitat by Barred Owls (Dugger et al. 2011).

To assess whether benefits of commercial thinning outweigh adverse impacts to spotted owls in dry forests (USFWS 2011), quantitative assessments are needed that allow for direct assessment of the amounts of any dense, mature or late-successional habitat that would be reduced by both commercial prescriptions and severe fire. Accordingly, we calculated these amounts by projecting them over 40 years and incorporated into our calculations the effects of forest regrowth. For our calculations, we used empirical data on fire and forest regrowth from the potential habitat within the two dry forest regions where spotted owls occur, the Klamath and dry Cascades of California, Oregon, and Washington, that are subject to thinning. We analyzed each region separately using region-wide data. Conservation planning for spotted owls commonly occurs at the scale of these regions. For our thinning treatment, we chose a "best" scenario for minimizing the amount of dense, latesuccessional forest to be treated (Lehmkuhl et al. 2007); while we used an optimistic scenario for treatment efficacy, assuming that a $50 \%$ reduction in high-severity fire would occur (Ager et al. 2007). We also illustrate the effects of varying treatment amount and efficacy. To calculate 
rotations of severe fire in the forests of the study area, we used available fire data from a time period, 1996-2011, which includes exceptionally large, rare fire events. Our approach may be useful to managers interested in maintaining habitat for other species that rely on dense forests in fire-prone regions (Odion and Hanson 2013).

\section{METHODS}

\section{Study Area}

We analyzed fire and forest recruitment trends in 19,000 $\mathrm{km}^{2}$ of dry forests in the Klamath and $18,400 \mathrm{~km}^{2}$ in the Cascades provinces. As in Hanson et al. (2009), we analyzed only late-successional, or "older" forests present in 1995, as mapped by Moeur et al. (2005). This is a small fraction of the dry forest regions. Our analysis was further restricted to federal lands. Mapping by Moeur et al. (2005) corresponds to mid-montane forest zones where Northern Spotted Owls occur. These montane forest zones include forests dominated mainly by true firs (A. grandis, A. concolor), Douglas-fir (Pseudotsuga menziesii), and Ponderosa pine ( $P$. ponderosa): Other conifers found in the central and northern Cascades in dry forests frequented by spotted owls are western hemlock (Tsuga heterophylla), western larch (Larix occidentalis), and limited amounts of western red cedar (Thuja plicata) and Engelmann spruce (Picea engelmannii). Forests in the Klamath are noted for high conifer diversity, with species such as incense cedar (Calocedrus decurrens) commonly found in the range of spotted owls. A variety of broad-leaved evergreen trees, such as madrone (Arbutus menziesii) and tanoak (Lithocarpus densiflorus) are also characteristic of these forests (Whittaker 1960).

\section{Quantifying Future Habitat}

We determined existing rates of dry-forest redevelopment following stand initiation in the forests of the study regions as delineated by Mouer et al. (2005) using the extensive U.S. Forest Service Forest Inventory and Analysis (FIA) forest monitoring data (http://www.fia.fs.fed.us/toolsdata/). FIA is a monitoring system based on one permanent, random plot per $\sim 2400$ ha across forested lands. We excluded plots from forests not used by spotted owls (e.g. lodgepole pine, oak forest) and from non-conifer vegetation and non-federal lands. Most of these plots were already excluded by the mapping by Mouer et al. (2005) that delineated the study area.

An FIA plot consists of a 1-ha area. For tree measurements, this area is sub-sampled with four circular subplots that are 0.1 ha for large-tree sampling and 0.017 ha for smaller-tree sampling (defined by region). The diameterat breast-height ( $\mathrm{dbh}$ ) and crown position of each tree and the ring count from two cores from dominant/codominant trees are measured in each subplot (USFS 2010). Stand age for an FIA plot is determined from the average of all ring counts from sub-plot samples, weighted by cover of sampled trees, and 8 years are added for estimated time to grow to breast height $(1.4 \mathrm{~m})$. We used live-tree dbh data to prepare regressions with stand age.
FIA data were available from 2001-2009, comprising $90 \%$ of the plots available within our study area. A total of 581 plots from the Klamath and 441 from the dry Cascades were considered, representing 13,944 and $10,680 \mathrm{~km}^{2}$ in each region, respectively. The number would be higher, but we eliminated 139 plots in the Klamath and 141 in the Cascades that had different stand-initiation dates from different subplots of the main FIA plot. This situation occurs throughout the study area due to the patchy nature of mixedseverity fire. Including all the subplots as individual plots creates a larger sample size, but we chose not to do this because some individual locations would be overrepresented. Most importantly, both approaches lead to the same results.

We analyzed fire severity from 1996-2011 in latesuccessional, or "older" forests mapped by Moeur et al. (2005). For 1996-2008, we used the Monitoring Trends in Burn Severity (MTBS) (http://www.mtbs.gov/) data. We used the ordinal classification from MTBS, as MTBS analysts determine for each fire where significant thresholds exist in digital prefire and postfire images, supplemented with plot data and analyst experience with fire effects. In plot data, a composite burn index that sums mortality by vegetation stratum is used to identify high fire severity (see http://www.mtbs.gov/). For 2009-2011, we obtained U.S. Forest Service digital data (http://www.fs.fed.us/postfirevegcondition) and classified these data following Miller and Thode (2007). We could not use pre-1996 MTBS fire severity data because the pre-burn map of spotted owl forest habitat is from 1995 (Moeur et al. 2005). From severity data we calculated high-severity fire rotation $\left(\mathrm{FR}^{\mathrm{hs}}\right)$, the expected time to severely burn an area equivalent to the area of interest once, or the landscape mean interval for severe fire (Baker 2009).

We calculated annual high-severity fire and forest regrowth rates to future proportions for early-, mid- and mature or late-successional forests, denoted herein by "E," "M," and "L," respectively, using annual time steps. We defined late-successional forests by selecting a value, $27.5 \mathrm{~m}^{2} / \mathrm{ha}$. This amount corresponds with the maximum basal area that would be left according to currently implemented thinning prescriptions (USDI 2011). This is somewhat higher than the minimum basal area where spotted owls have been found to nest in dry forests. For example, the mean value minus one standard deviation in all the dry forest stands studied by Buchanan et al. (1995) was $23 \mathrm{~m}^{2} / \mathrm{ha}$. However, we did not want to identify the rate of regrowth to the very minimum basal area that constitutes habitat, but regrowth to a basal area more likely to function as habitat. Mid- and early-successional forests were defined as 13.527.5 and $<13.5 \mathrm{~m}^{2} /$ ha tree basal area, respectively. We separated mid-successional from early-successional forest because, mid-successional forests may be included in thinning treatments, but early-successional forests may not. Thinned forest ("T") was our fourth vegetation state. The forest states are diagramed in Fig. (1). The proportion of each state in the landscape at time $t$, defined a vector $\left(\mathrm{P}_{t}^{E}\right.$, $\left.\mathrm{P}_{t}^{M}, \quad \mathrm{P}_{t}^{T}, \quad \mathrm{P}_{t}^{L}\right)$. Transition probabilities $\phi_{t}^{r s}$ equaled the probability that any portion of state $r$ at time $t$ transitions to 


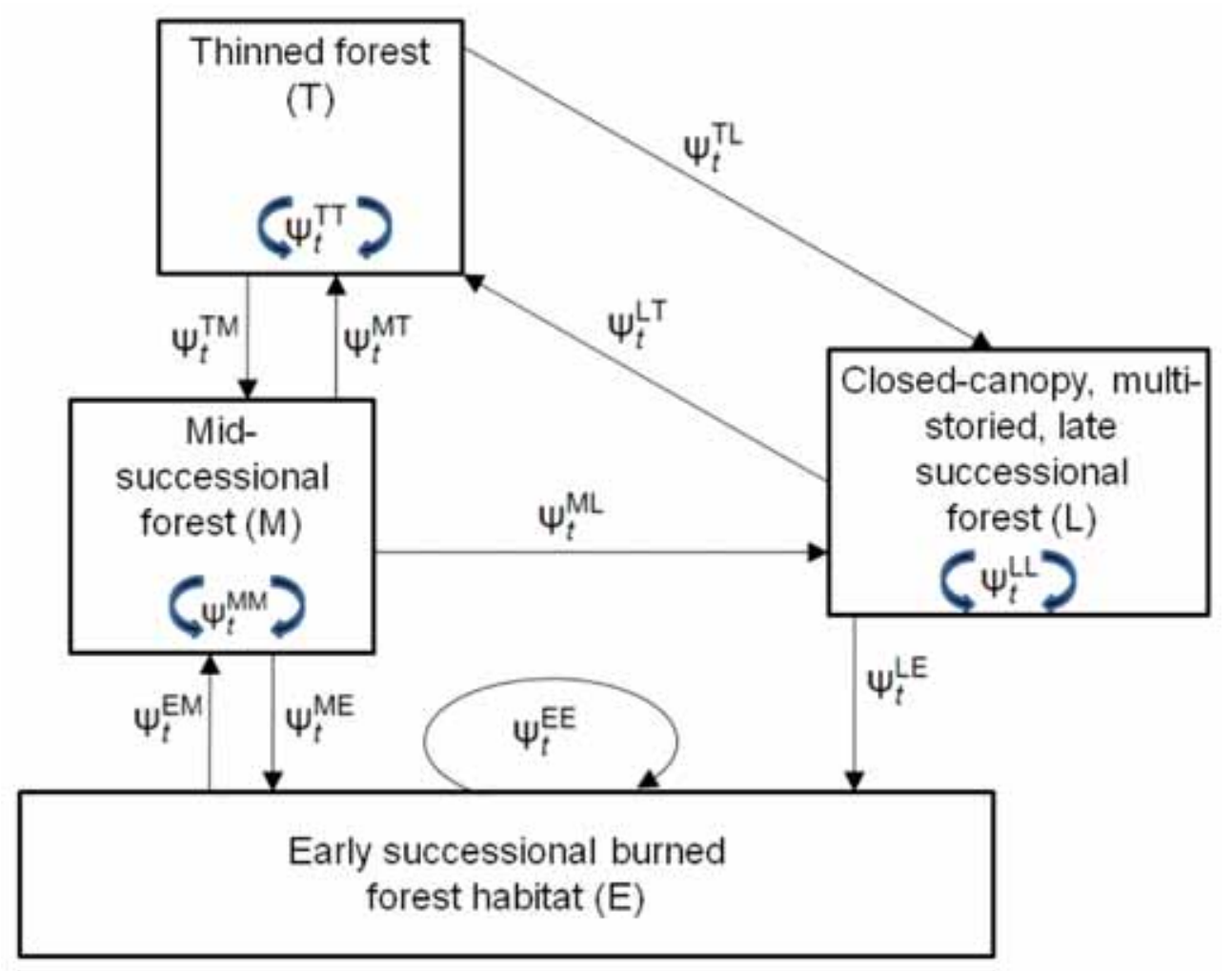

Fig. (1). State (boxes) and transition (arrows) model for dry Pacific Northwest Forest vegetation with fire disturbances and thinning. Variables are the transition rates between states indicated by the associated arrow.

state $s$ at time $t+1$, allowing calculation of future amounts of each forest type using the following equation:

$\left[\begin{array}{c}\phi_{t}^{E E} \phi_{t}^{M E} \phi_{t}^{T E} \phi_{t}^{L E} \\ \phi_{t}^{E M} \phi_{t}^{M M} \phi_{t}^{T M} \phi_{t}^{L M} \\ \phi_{t}^{E T} \phi_{t}^{M T} \phi_{t}^{T T} \phi_{t}^{L T} \\ \phi_{t}^{E L} \phi_{t}^{M L} \phi_{t}^{T L} \phi_{t}^{L L}\end{array}\right]\left[\begin{array}{c}\mathrm{P}_{t}^{E} \\ \mathrm{P}_{t}^{M} \\ \mathrm{P}_{t}^{T} \\ \mathrm{P}_{t}^{L}\end{array}\right]=\left[\begin{array}{c}\mathrm{P}_{t+1}^{E} \\ \mathrm{P}_{t+1}^{M} \\ \mathrm{P}_{t+1}^{T} \\ \mathrm{P}_{t+1}^{L}\end{array}\right]$

The initial proportions, $\mathrm{P}_{t=0}^{\mathrm{E}-\mathrm{L}}$ of the three natural-forest states were from the FIA basal-area analyses, with thinned forests considered zero for simplicity and because of lack of data. The annual transition from mid- and late- to earlysuccessional forest from high-severity fire $\left(\phi_{t}^{L E}, \phi_{t}^{M E}\right)$ was $1 / \mathrm{FR}^{\mathrm{hs}}$. Early-successional forests also burned at this rate $\left(\phi_{t}^{E E}\right)$. Annual rates of forest redevelopment were from the inverse of the growth period $\left(1 / \mathrm{G}^{\mathrm{EM}}\right)$ to reach $13.5 \mathrm{~m}^{2} / \mathrm{ha}$ live-tree basal area, or to grow from 13.5 to $27.5 \mathrm{~m}^{2} /$ ha livetree basal area $\left(1 / \mathrm{G}^{\mathrm{ML}}\right)$, calculated from the regression of live basal area on age (see results). Lower-severity fire can reduce basal area from $>27.5 \mathrm{~m}^{2} /$ ha basal area to $<27.5$ $\mathrm{m}^{2} /$ ha. However, this transition is already considered in the regrowth rate, which also incorporates the effects of lowerseverity fires that have occurred on rates of forest redevelopment. Because natural disturbances that may temporarily lower basal area are captured in the transitions from early- to late-successional forest, the transition from late to mid-successional forest was set to zero. Transition rates to thinned forest were based on treatment within 20 years, beginning in year $t+1$, of the mid- and latesuccessional forests present at $t=0$ (see Table $\mathbf{1}$ for annual rate). Based upon the empirical FIA and MTBS data described above, we used these transitions (Table 1) and Eq. 1 to project forward 40 years (see sample calculation in the Supplementary Materials). We chose this time interval because it represents one cycle of thinning and forest recovery.

Next, we calculated the effects of varying levels of thinning, and treatment efficacy (in terms of the effect on high-severity fire rotation intervals), over the study period. According to an analysis of a spotted owl landscape by Lehmkuhl et al. (2007), a "best" scenario for minimizing the short-term adverse impacts of thinning while reducing fire frequency and severity was one that treated only $22 \%$ of the landscape, and limited thinning in nesting, roosting, and foraging habitat to $21 \%$ of the area of this habitat. We used this prescription in our calculations to illustrate the effects under a best-case scenario. In our calculations, the amount of mid-successional forest thinning differed between the two regions because amounts of both mid- and late-successional forests were not the same. We also considered the effects of treating from 0 to $45 \%$ of forests, holding constant the proportions of treatments that were in late-successional vs. mid-successional forests.

We assumed that there would be no high-severity fire in treated forests over the treatment lifespan. We additionally assumed that thinning $22 \%$ of the landscape would lower the amount of high-severity fire in the unthinned landscape by half. This is based on the findings of Ager et al. (2007) who simulated the effects of wildfire ignitions following strategic 
Table 1. Annual transition probabilities used in transition matrices for each scenario analyzed for dry provinces within the range of the Northern Spotted Owl. FR ${ }^{\text {hs }}$ is the high-severity fire rotation. $G$ is the time required for stands to grow from early to mid- (EM) or mid- to late-successional (ML) forest (see Table 2). $K=$ Klamath, $C=$ Cascades. $R$ is the amount that high severity fire is reduced by thinning $(50 \%$ reduction at 22 percent of late-successional forest thinned).

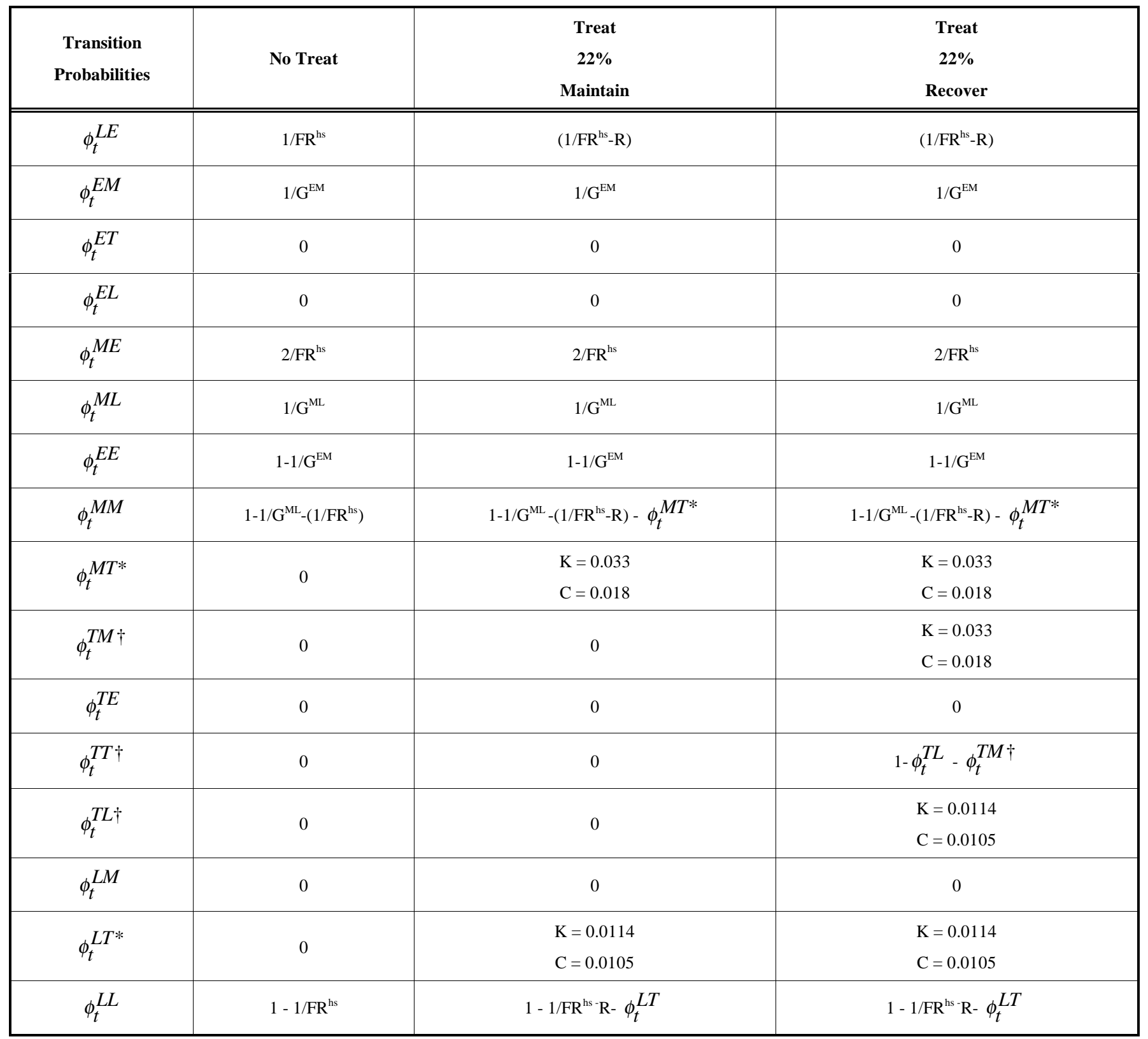

* Only in effect for the first 20 years.

$\dagger$ Does not take effect until after 20 years.

thinning treatments in a spotted owl landscape. When $<22 \%$ of the landscape was affected at any given time (such as any time prior to year 20 when the full treatment would be incomplete, or after one-time treatments began to recover, or for scenarios with $<22 \%$ of the landscape treated) the same ratio of area treated to reduction in high-severity fire $(22 \%$ treat: $50 \%$ reduction in fire) was used to reduce the area burned at high severity (see Supplementary Material for an illustration). Thus, the amount that fire was reduced by thinning increased with each year as a function of the total area thinned (all other variables were constant). Ager et al. (2007) found little additional effect of treatments in reducing wildfires as treatment level increased beyond $20 \%$, so we did not calculate greater reductions in fire as treatment levels went from $22-45 \%$. However, we additionally calculated future habitat amounts as a function of fire rotation to evaluate the effects of varying treatment efficacy, in which case we did calculate the reduced amount of habitat burned severely. This amount is the dependent variable in our summary figures. Treatment lifespan was assumed to be 20 years (Rhodes and Baker 2008) for "one-time thinning," or maintained in perpetuity over the 40 years for "maintained." A sample calculation using the model (equation 1) is presented in the Supplementary Material. 


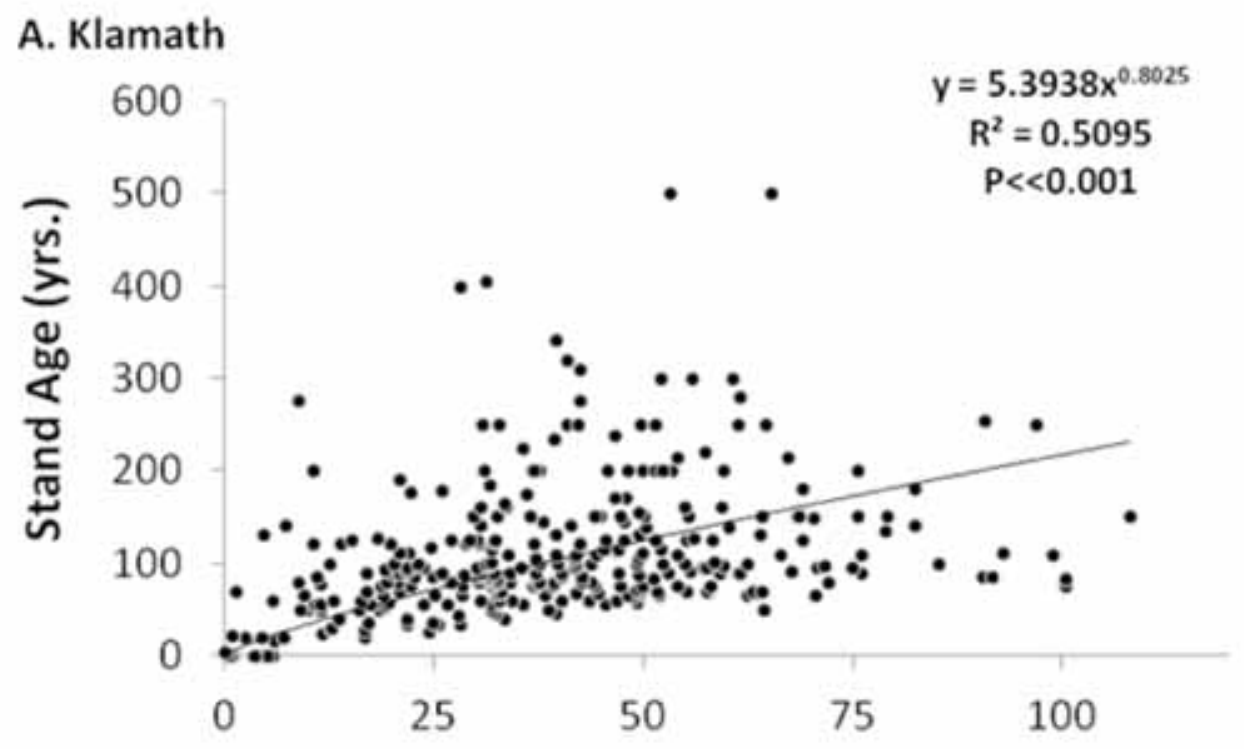

\section{B. Dry Cascades}

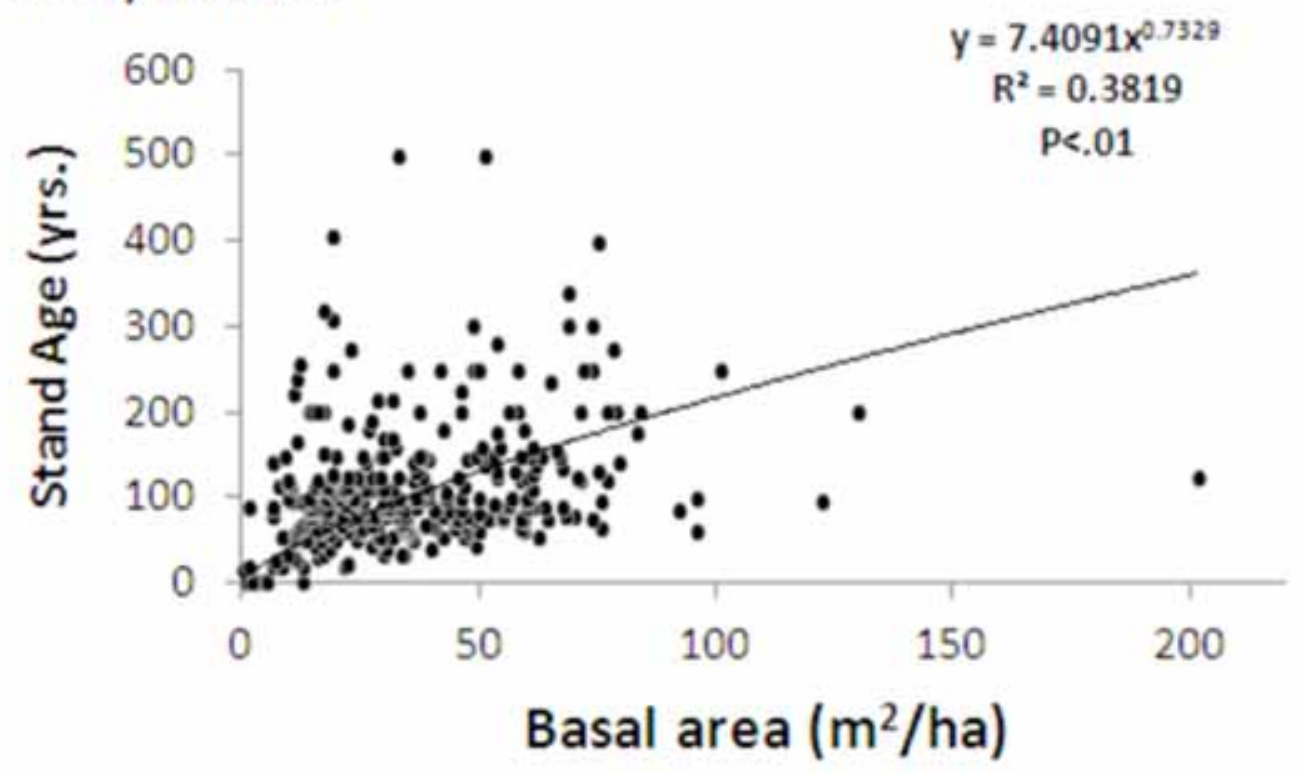

Fig. (2a-b). Scatterplots of live-tree basal area per hectare and stand age from US Forest Service FIA data for the A. Klamath region and B. dry Cascades region.

The only owl habitat we considered for impacts from thinning was suitable nesting, roosting, and foraging (so called NRF habitat). Because treatments aimed at demonstrating the type of thinning to be implemented in spotted owl habitat reduce basal area down to 13.75-27.5 $\mathrm{m}^{2} /$ ha, mostly well-below the minimum amounts for NRF habitat (Pidgeon 1995, Buchanan and Irwin 1998, LeHaye and Gutiérrez 1999), and because treated forests also have reduced amounts of key habitat features like multi-canopy structure, down wood, small firs and mistletoe infections, the area affected by these treatments will largely correspond to the amount of habitat lost. Thinning may also render adjacent, unthinned forest unsuitable or less suitable (Seamans and Gutiérrez 2007), but we did not account for this effect. The lifespan for thinning treatments that we used was 20 years for one-time thinning (Rhodes and Baker
2008), and 40 years for maintained treatments. Transition from late- to early-successional vegetation due to highseverity fire also was considered habitat loss. This may overestimate the impacts of fire on Northern Spotted Owl foraging habitat (Bond et al. 2009, USFWS 2011), but the assumption is largely irrelevant due to the low rates of highseverity fire in both study regions in relation to forest regrowth, as described next.

\section{RESULTS}

We found a highly significant relationship between livetree basal area and stand age in both regions (Figs. 2a-b, Klamath $n=442$, dry Cascades $n=304$ ). Much of the variance in the plot data was caused by a modest number of relatively old stands that had much lower basal area for their 
Table 2. Forest Inventory and Analysis (FIA) plot parameters for the Klamath and dry Cascades provinces, California, Oregon, and Washington, based on most recent survey data from 2001-2009. Also shown are the amounts of time after fire that is takes forest to regrow to the specified live basal area (BA) thresholds using the regression equations shown in Figs. (2a-b). ${ }^{\mathrm{a}}$ These plots have 2 or more stand ages associated with them due to different disturbance histories within the main FIA plot.

\begin{tabular}{|l|c|c|}
\hline \multicolumn{1}{|c|}{ Entity } & Klamath & Dry Cascades \\
\hline \hline Number of plots (total) & 581 & 445 \\
\hline Number of plots excluded from analysis $\dagger$ & 939 & 141 \\
\hline Initial $\left(\mathrm{P}_{t+0}^{E}\right)$ early-successional forest (\%) & 9 & 14.5 \\
\hline Initial $\left(\mathrm{P}_{t+0}^{M}\right)$ mid-successional forest (\%) & 14.4 & 26.9 \\
\hline Initial $\left(\mathrm{P}_{t+0}^{L}\right)$ late-successional forest (\%) & 76.6 & 55.6 \\
\hline Regrowth period, $0-13.5 \mathrm{~m}^{2} / \mathrm{ha}$ live BA (yrs) & 44 & 53 \\
\hline Regrowth period, $13.5-27.5 \mathrm{~m} / \mathrm{ha}$ live BA (yrs) & 32 & 36 \\
\hline Regrowth period, $0-27.5 \mathrm{~m}^{2} / \mathrm{ha}$ live BA (yrs) & 76 & 89 \\
\hline High-severity fire rotation & 362 & 913 \\
\hline
\end{tabular}

$\dagger$ These plots have 2 or more stand ages associated with them due to different-aged sub-plots within the main FIA plot.

age than did other plots. The amount of time following disturbance needed for regenerating forests to reach live-tree basal area $>27.5 \mathrm{~m}^{2} /$ ha was 77 and 90 years, respectively, for the Klamath and dry Cascades (Table 2).

Using the MTBS data, the rotation for high-severity fire from 1996-2011 was 362 to 913 years in the Klamath and dry Cascades, respectively (Table 2). At these rates, a total of 1,221 and $325 \mathrm{~km}^{2}$ of high-severity fire would occur in Klamath and dry Cascades late-successional forests, respectively, in 40 years. With annual regrowth rates of latesuccessional forests that were 4.5 to $>10$ times greater than the rates of fire disturbances (i.e. $(1 / 77) /(1 / 362)$ for the Klamath and $(1 / 89) /(1 / 913)$ for the dry Cascades, and no disturbances other than fire, late-successional forests would eventually come to occupy $83 \%$ of the potential forested area in the Klamath and $91 \%$ in the Cascades. Thus, over 40 years, late-successional forests in the Klamath increased slightly over their current amount of $77 \%$ of the forested landscape FIA plots to $81 \%$ or from about $10,668 \mathrm{~km}^{2}$ to $11,335 \mathrm{~km}^{2}$ (Fig. 3a). In the dry Cascades, where latesuccessional forests were $59 \%$ of the forested landscape FIA plots, they increased relatively rapidly to $77 \%$ of the forested landscape, or from $6,253 \mathrm{~km}^{2}$ to $8,234 \mathrm{~km}^{2}$ in 40 years (Fig. 4a).

Simulated thinning of $21 \%$ of dense, late-successional forest of the Klamath landscape meant that a total of 2,225 $\mathrm{km}^{2}$ would be reduced, while treatments in mid-successional forests would cover $840 \mathrm{~km}^{2}$ to reach a treatment level of $22 \%$ of the whole landscape. After the one-time thinning, late-successional forests returned to slightly lower amounts than occurred without thinning after 40 years (Fig. 3a). The net effect of the one-time thinning was to reduce latesuccessional habitat by $10.7 \%$ over the 40 -year period, or from an average of $11,086 \mathrm{~km}^{2}$ to $9,996 \mathrm{~km}^{2}$ over 40 years (i.e., 1,090 $\mathrm{km}^{2}$ less each year on average, Fig $3 \mathbf{b}$ ). The amount of dense, late-successional forest that was prevented from burning at high severity was $16 \mathrm{~km}^{2} /$ year, resulting in $320 \mathrm{~km}^{2}$ of dense, late-successional forest, which would otherwise have been transformed into early-successional forest, in each year on average over the 40-year period. Therefore, in this scenario, thinning reduced 3.4 times more late-successional forest than it increased. The maintained treatment reduced habitat by $15.3 \%$, from $11,086 \mathrm{~km}^{2}$ on average over 40 years to $9,396 \mathrm{~km}^{2}$ (i.e., $1,690 \mathrm{~km}^{2}$ less each year on average, Fig. 3c). In both cases, $13 \%$ of the habitat loss was from thinning in mid-successional forest that prevented or slowed these forests from developing into dense, late-successional forest. The amount of dense, latesuccessional forest that was prevented from burning at high severity was $20 \mathrm{~km}^{2} /$ year, resulting in $400 \mathrm{~km}^{2}$ of dense, late-successional forest, which would otherwise have been transformed into early-successional forest, in each year on average over the 40 -year period. Therefore, the combination of thinning and maintenance reduced 4.2 times more latesuccessional forest than it increased.

In the Cascades, to treat $22 \%$ of the landscape, the thinning scenario targeted $1,313 \mathrm{~km}^{2}$ of dense, latesuccessional forest, and $1,036 \mathrm{~km}^{2}$ of mid-successional forest. After the one-time thinning, late-successional forests again returned to slightly lower amounts than occurred without thinning after 40 years (Fig. 4a). The net effect of the one-time thinning treatment over 40 years was to reduce dense, late-successional forest by an average level of $11.1 \%$ $\left(836 \mathrm{~km}^{2}\right.$ less each year on average, Fig. $\left.4 \mathbf{b}\right)$. The amount of dense, late-successional forest that was prevented from burning at high severity from the one time treatment was $3.5 \mathrm{~km}^{2} /$ year, resulting in $140 \mathrm{~km}^{2}$ of dense, late-successional forest, which would otherwise have been transformed into 


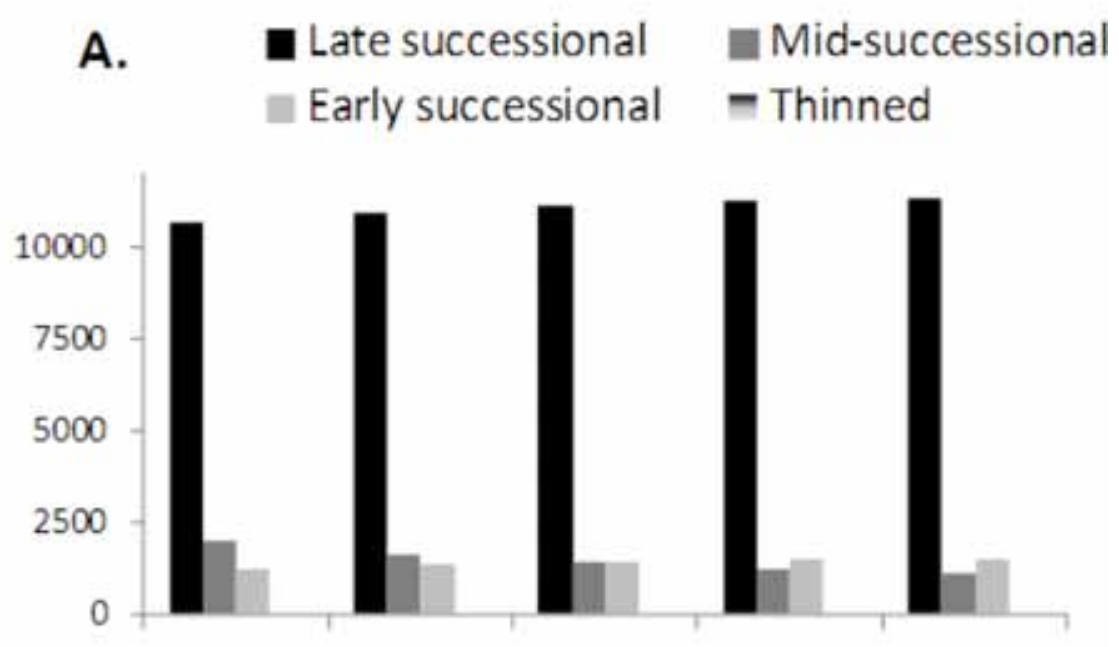

B.

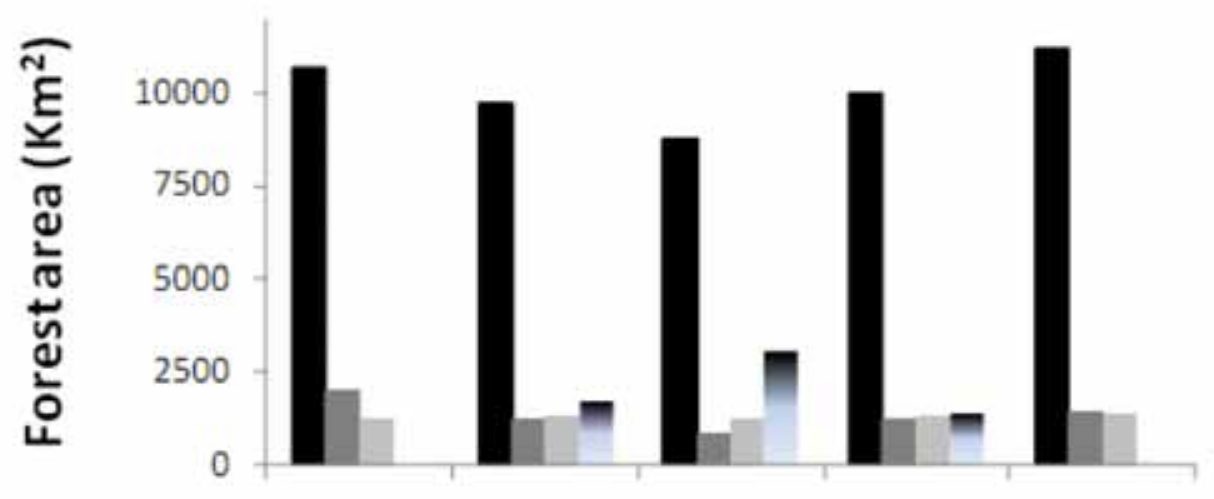

\section{C.}

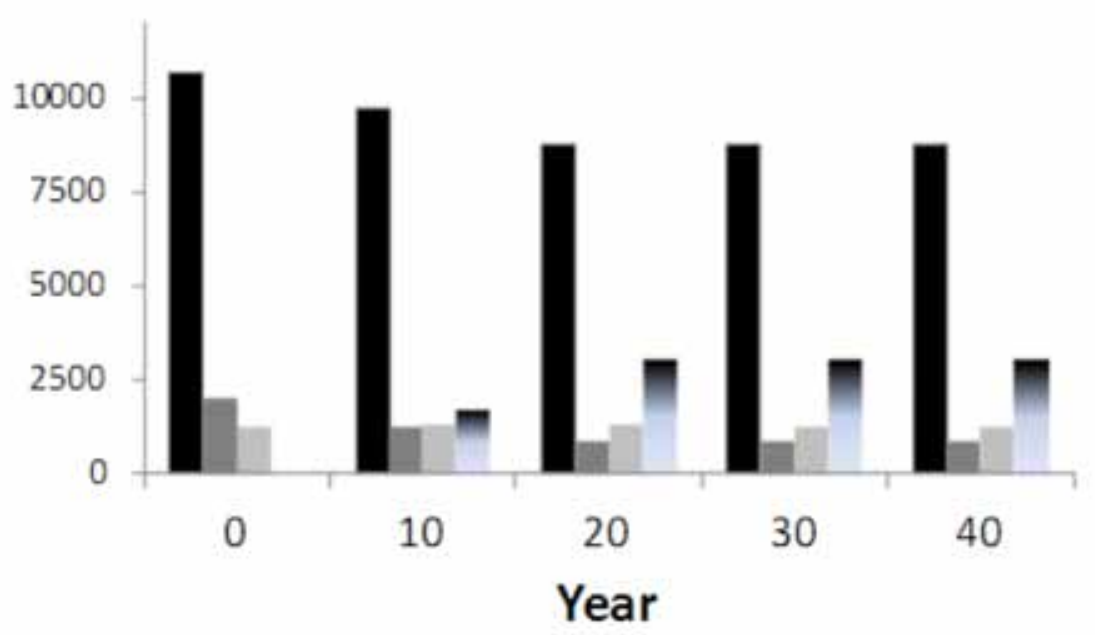

Fig. (3a-c). Amounts of the four forest types (early-, mid-, late-successional, and thinned) in the landscape over a 40-year period based on the states shown in (Fig. 1) and transition rates (Table 2) for the Klamath province, California, and Oregon, and the following scenarios: A) no treatment; B) one-time treatment of $21 \%$ of late-successional forests $\left(>27.5 \mathrm{~m}^{2} /\right.$ ha live-tree basal area) and $42 \%$ of mid-successional forests (= total of $22 \%$ of landscape treated) followed by recovery in 20 years to late-successional forest; C) treatment of $21 \%$ of late-successional forests $\left(>27.5 \mathrm{~m}^{2} /\right.$ ha live-tree basal area) and $42 \%$ of mid-successional (= total of $22 \%$ of landscape treated) forests with future maintenance. We converted proportions of forest types from modeling output to $\mathrm{km}^{2}$ using the area estimate from FIA for the Klamath study region. 


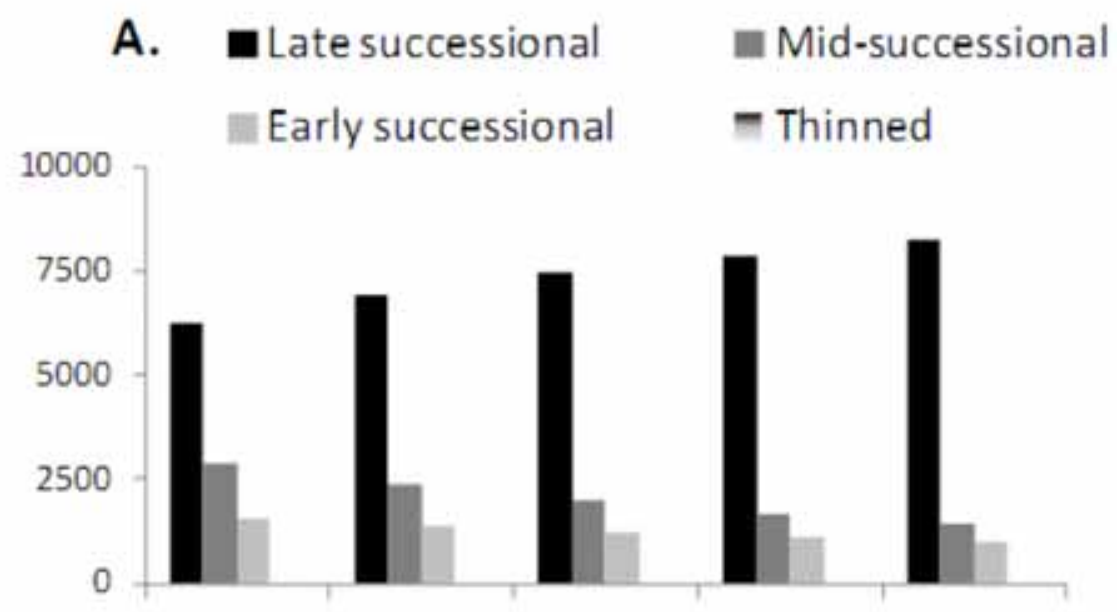

B.

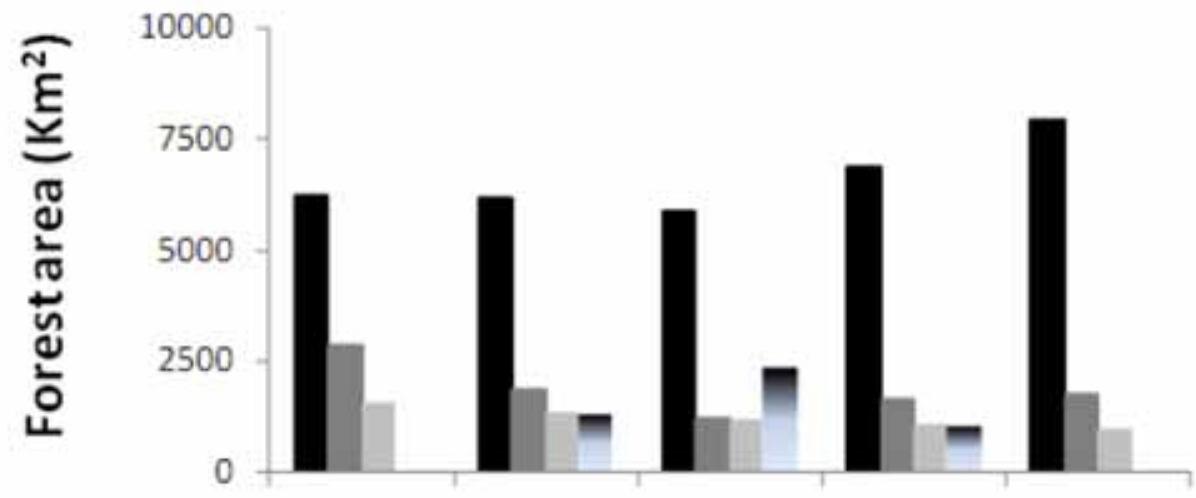

C.

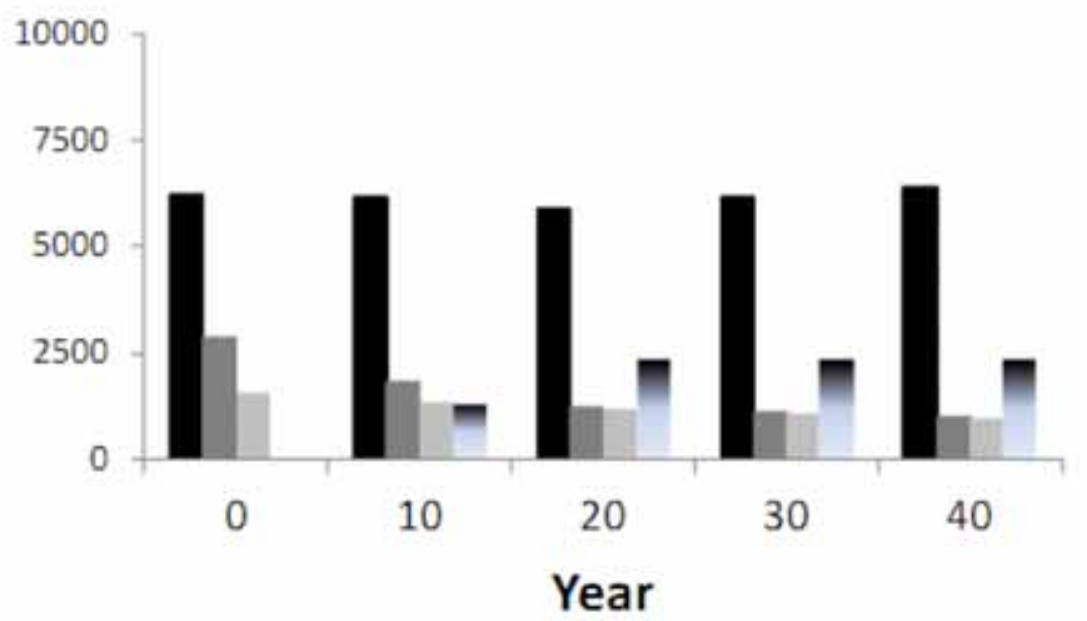

Fig. (4a-c). Amounts of the four forest types (early-, mid-, late-successional, and thinned) in the landscape over a 40-year period based on the states in (Fig. 1) and transition rates (Table 2) for the dry Cascades province, California, Oregon, and Washington and the following scenarios: A) no treatment; B) one time treatment of $21 \%$ of late-successional forests $\left(>27.5 \mathrm{~m}^{2} / \mathrm{ha}\right.$ live tree basal area) and $36 \%$ of midsuccessional forests $(=22 \%$ of landscape treated) followed by recovery in 20 years to late-successional forest; C) treatment of $21 \%$ of latesuccessional forests $\left(>27.5 \mathrm{~m}^{2} /\right.$ ha live tree basal area) and $36 \%$ of mid-successional forests (=22\% of landscape treated) in perpetuity. We converted proportions of forest types from modeling output to $\mathrm{km}^{2}$ using the area estimate from FIA for the dry Cascades study region.

early-successional forest, in each year on average over the 40-year period. Therefore, thinning reduced 6.0 times more late-successional forest than it increased. The maintained treatment reduced dense, late-successional forest by an average of $16.4 \%\left(1,212 \mathrm{~km}^{2}\right.$ less each year on average, Fig. 4c). Of this reduction, $30 \%$ was from the indirect effect of thinning in mid-successional forests, more of which were treated in the Cascades scenario. The amount of dense, late- 

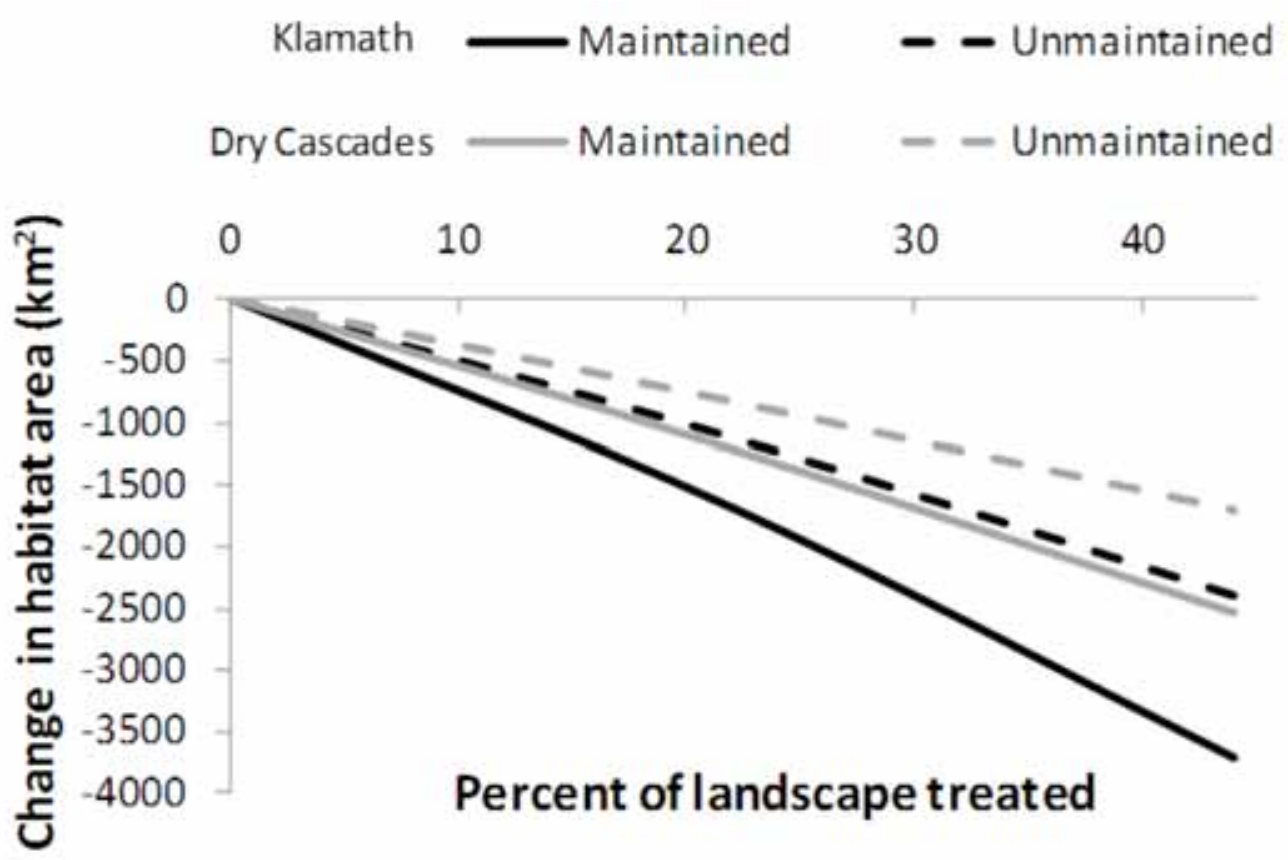

Fig. (5). Net amount of habitat lost over 40 years compared to the no-treatment scenario as a function of treatment of $0-45 \%$ of the landscape. The amount of late-successional forest treated was held constant at $21 \%$ of the area of this forest, except at very low levels of treatment. The amount of mid-successional forest treated varied from zero at very low treatment levels, to a large proportion of the midsuccessional forests when $45 \%$ of the landscape was treated, particularly in the Klamath region.

successional forest that was prevented from burning at high severity from the maintained treatment scenario was 4.5 $\mathrm{km}^{2} /$ year, resulting in $180 \mathrm{~km}^{2}$ of dense, late-successional forest, which would otherwise have been transformed into early-successional forest, in each year on average over the 40-year period. Therefore, the combination of thinning and maintenance reduced 6.7 times more late-successional forest than it increased.

As treatment level increased from 11 to $22 \%$, habitat loss doubled (Fig. 5). With $22 \%$ of the landscape treated, the effect of reducing fire by $50 \%$ in the rest of the landscape was reached, and there was no further reduction in fire with increasing treatment amount. With less fire prevented per $\mathrm{km}^{2}$ treated, the rate of habitat loss increased as treatment went from 22 to $45 \%$ of the landscape.

We also assessed the effect of holding treatment level constant and varying the efficacy of treatments. Even if treatment efficacy was considerably greater than we assumed and rotations of high-severity fire substantially longer than twice their current length, the amount of dense, latesuccessional forest habitat that would be reduced due to thinning would only be slightly lower (Figs. 6a-b). With complete elimination of fire over 40 years as a result of treatments, the amount of dense, late-successional forest would be $9-10 \%$ less than with no treatment. This becomes a large amount of habitat loss over time.

\section{DISCUSSION}

We found that the habitat recruitment rate exceeded the rate of severe fire by a factor of 4.5 in the Klamath and 10 in the dry Cascades, leading to a deterministic increase in dense forest habitat over time, assuming no other disturbance events. In contrast, previous published assessments of fire on spotted owls have not explicitly considered fire and forest regrowth rates (Wilson and Baker 1998, Lee and Irwin 2005, Roloff et al. 2005, 2012, Calkin et al. 2005, Hummel and Calkin 2005, Ager et al. 2007, Lehmkuhl et al. 2007). Not including the probability of high-severity fire, which is low, leads to highly inflated projections of the effects of thinning versus not thinning on high-severity fire (Rhodes and Baker 2008, Campbell et al. 2012).

Our calculations of thinning effects included rates of forest regrowth along with high-severity fire. The calculations illustrate how the requirement that the long-term benefits of thinning clearly outweigh adverse impacts (USFWS 2011) is not attainable as long as treatments have adverse impacts on spotted owl habitat. This is because the amount of dense, late-successional forest that might be prevented from burning severely would be a fraction of the area that would be thinned. Under our "best case" scenario, thinning reduced dense, late-successional forest by 3.4 and 6.0 times more than it prevented such forest from experiencing high-severity fire in the Klamath and dry Cascades, respectively, similar to findings in a recent unpublished report by U.S. Forest Service scientists from the Pacific Northwest Research Station (Raphael et al. 2013). This would not be a concern if thinning effects were neutral, but the commercial thinning prescriptions being implemented call for forests with basal area reduced by nearly half to $13.5-27.5 \mathrm{~m}^{2} / \mathrm{ha}$, which is mostly well below the minimum level known to function as nesting and roosting habitat (ca. $23 \mathrm{~m}^{2} / \mathrm{ha}$ ) (Buchanan et al. 1995, 1998). Thus, if dense forests are subjected to these treatments, much of the impacted area would no longer have minimum basal area needed to function as nesting and roosting habitat. Even an immediate doubling of fire rates due to climate change or 


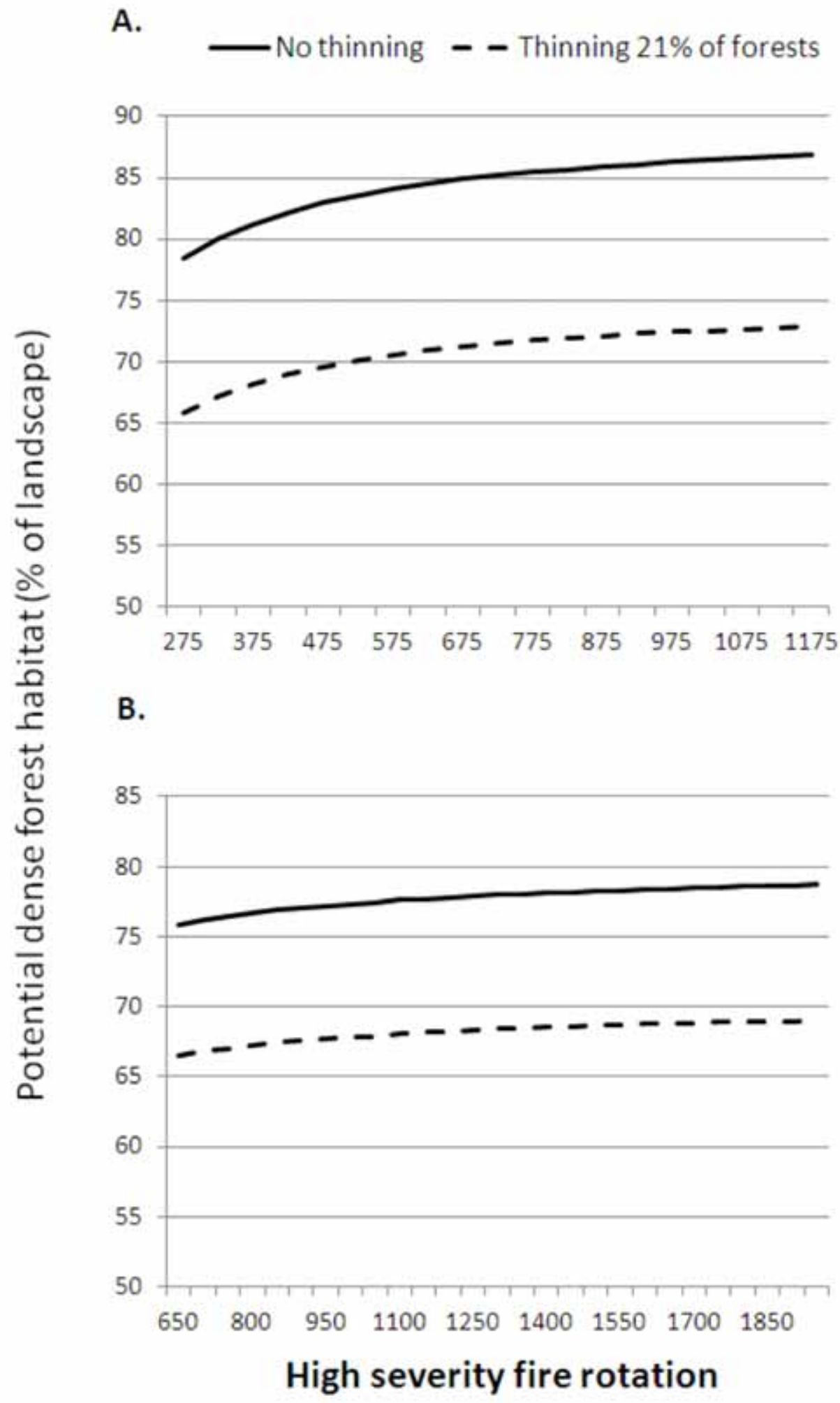

Fig. (6a-b). Amount of forest habitat in the range of the Northern Spotted Owl in the A. Klamath, and B. dry Cascades 40 years in the future as a function of the average high severity rotation over that time period, and longer rotations.

other factors would result in far less habitat affected by highseverity fire than thinning. In addition, much of the highseverity fire might occur regardless of thinning, especially if the efficacy of thinning in reducing high-severity fire is reduced as fire becomes more controlled by climate and weather (Cruz and Alexander 2010). Clearly, the strategy of trying to maintain more dense, late-successional forest habitat by reducing fire does not work if the method for reducing fire adversely affects far more of this forest habitat than would high-severity fire, and the high-severity fire might occur anyway because it is largely controlled by climate and weather. 
There may be silvicultural treatments that can be done in spotted owl habitat that may reduce adverse impacts. For example, thinning that maintains at least $23-27.5 \mathrm{~m}^{2}$ ha basal area. However, given that key habitat elements such as small trees, down wood, and likely some intermediate-sized trees are going to be targeted in any forest fuel reduction treatment, it appears unlikely that any conventional fuels reduction treatment in spotted owl habitat would not have at least some adverse impacts. This is supported by research on thinning that was often less intensive than commercial thinning prescriptions. This research showed negative impacts on spotted owls or their prey, as summarized in our introduction (Waters and Zabel 1995, Waters et al. 2000, Carey 2001, Ransome and Sullivan 2002, Gomez et al. 2003, Suzuki and Hayes 2003, Ransome et al. 2004, Bull et al. 2004, Lehmkuhl et al. 2006, Meyer et al. 2007, Wilson 2010, Holloway and Smith 2011, Manning et al. 2012), and how spotted owls have been displaced by even very limited amounts of thinning or contemporary harvest near the nest or activity center (Forsman et al. 1984, King 1993, Hicks et al. 1999, Meiman et al. 2003, Seamans and Gutiérrez 2007). Even if adverse impacts were quite modest, the amount of dense, late-successional forest that might be prevented from experiencing high-severity fire is so much smaller than the area that would be treated in an effort to accomplish this reduction in fire, that the net impact of the thinning would still be much greater. In addition, it is becoming increasingly less clear whether a reduction in high-severity fire below current rates would necessarily be beneficial to spotted owls. The dry forests in which spotted owls are found were historically characterized by mixed-severity fires (see Hessburg et al. (2007), Baker (2012), and Odion et al. (2014) for historic fire in the dry Cascades of Washington and Oregon, Beaty and Taylor (2001) and Bekker and Taylor (2001, 2010) for the California Cascades, and Wills and Stuart (1994), Taylor and Skinner (1998, 2003), and Odion et al. (2014) for the Klamath). Recent research suggests that this historic fire may have neutral and beneficial effects to spotted owls.

Studies on the effects of fire on spotted owls are few and often focused on other owl subspecies and some studies are confounded by post-fire logging effects (Clark et al. 2013). Nonetheless, it has long been known that fire in woody vegetation causes an increase in small rodent populations and consequently raptor populations (Lawrence 1966), and studies on spotted owls and fire where no logging occurred suggest that high-severity fire at current rates may confer benefits or be neutral. Bond et al. (2009) found that California Spotted Owls in the Sierra Nevada preferentially foraged in severely burned forests more than unburned forests within about $1.5 \mathrm{~km}$ of a core-use area. The percentage of high-severity fire in burned Mexican Spotted Owl (Strix occidentalis ssp. lucida) sites had no significant influence (Jenness et al. 2004). Roberts et al. (2011) found no support for an occupancy model for California Spotted Owls that distinguished between burned and unburned sites in unmanaged forests; the mean "owl survey area" that burned at high-severity was $12 \%$, with one survey area experiencing up to $52 \%$ high-severity fire, which is almost three times the current amount of severe fire in owl habitat, according to the MTBS data. In a longer-term (1997-2007) study of California Spotted Owl site-occupancy dynamics throughout the Sierra Nevada, high-severity fire that burned on average $32 \%$ of forested vegetation around nests and core roosts had no significant effect on extinction or colonization probabilities, and overall occupancy probabilities were slightly higher in mixed-severity burned areas than in unburned forest (Lee et al. 2012), while other research found no significant difference in home range size between mixedseverity fire areas and unburned forest (Bond et al. 2013). Studies on reproduction in occupied sites of all three spotted owl subspecies indicated no difference between unburned sites and mixed-severity burned sites (excluding burn out areas created by fire suppression operations) (Jenness et al. 2004), or in some cases reproduction may have been greater in burned sites (Bond et al. 2002, Roberts 2008). The longerterm value of fire disturbances is in the creation of landscape heterogeneity with inclusions of young stands, improving habitat at the landscape scale. Fire also plays a vital role in creating snags, large down logs, and other key elements of the highest quality spotted owl habitat at the territory scale (Franklin et al. 2000). No assessments of fire and thinning effects on spotted owls, including this one, have accounted for any potential beneficial effects of mixed-severity fire, nor the potential negative effects of lack of mixed-severity fire in treated areas.

While much of the concern about fire and thinning in dry forests of the Pacific Northwest has focused on spotted owls, it may also apply to other biota associated with dense, old forests, including species of conservation concern, such as Pacific fisher (Martes pennanti pacifica), which research indicates may benefit from mixed-severity fire (Hanson 2013), the Northern Goshawk (Accipiter gentilis), and, following fire, the Black-backed Woodpecker (Picoides arcticus), which depends upon higher-severity fire in dense, older forest (Odion and Hanson 2013). Like the spotted owl, studies have documented that this woodpecker is also negatively affected by thinning (Hutto 2008). Also, like the spotted owl, the Back-backed Woodpecker, Pacific Fisher and Northern Goshawk occur in forests where the historic fire regime was not low-severity. Modeling for the fisher, similar to modeling for the spotted owl, has not used the actual rates of high-severity fire and forest regrowth to assess possible impacts of fire, and has assumed that fire represents a loss of fisher habitat (Scheller et al. 2011), contrary to more recent empirical findings (Hanson 2013). Not including the actual probability of fire leads to considerably inflated projections of the effects of thinning vs. not thinning in reducing high-severity fire (Rhodes and Baker 2008, Campbell et al. 2012). Our findings highlight the need to be cautious about conclusions that thinning treatments are needed for species found in dense forest and that they will not have unintended consequences (e.g., Stephens et al. 2012) until long-term, cumulative impacts are better understood. As we found with spotted owls, long-term and unintended consequences may be substantial for species that rely on dense, late-successional forests, especially when these species are sensitive to small amounts of thinning in their territory.

\section{CONCLUSION}

We used a quantitative approach that, unlike others, accounted for rates of high-severity fire and forest 
recruitment, allowing assessment of future amounts of spotted owl habitat at current rates of fire, with and without thinning. We found that the long-term benefits of commercial thinning would not clearly outweigh adverse impacts, even if much more fire occurs in the future. This conclusion applies even if adverse impacts of treatments are quite modest because of the vastly larger area that would need to be treated compared to area of high-severity fire that might be reduced by thinning. Moreover, our results indicate that, even if a longer time interval is analyzed (e.g., 100 years), the declines in dense, late-successional habitat due to thinning would not flatten, as long as thinning is reoccurring. Thus, where spotted owl management goals take precedence, the best strategy for maintaining habitat will be to avoid thinning treatments that have adverse impacts in spotted owl habitat or potential habitat (Gaines et al. 2010). There is ample area outside of existing or potential spotted owl habitat where managers wishing to suppress fire behavior or extent may focus their efforts without directly impacting spotted owls (Gaines et al. 2010), such as in areas adjacent to homes or in dense conifer plantations with high fuel hazards (Odion et al. 2004). In addition, there are management approaches that may be more effective than thinning in helping accomplish these fire prevention goals, such as controlling human-caused fire ignitions (Cary et al. 2009). Lastly, emerging research suggests that fire is not the threat it has been assumed to be for spotted owls, suggesting that, rather than management that focuses on suppressing fire behavior, other, no regrets active management may be more appropriate (Hanson et al. 2010). Research is needed to determine if these findings might apply to other species that are characteristic of dense forests, particularly given the widespread and growing emphasis on thinning as a management tool for suppressing wildland fires.

\section{CONFLICT OF INTEREST}

The authors confirm that this article content has no conflict of interest.

\section{ACKNOWLEDGEMENTS}

We thank Tim Sinnott for GIS analyses and the anonymous reviewers for helpful comments on the manuscript. We also thank R. Anthony and Kelly Odion for helpful discussions.

\section{SUPPORTIVE/SUPPLEMENTARY MATERIAL}

Supplementary material is available on the publishers Web site along with the published article.

\section{REFERENCES}

Agee, JK, \& Skinner, CN (2005) Basic principles of forest fuel reduction treatments. Forest Ecology and Management, 211, 83-96.

Ager, AA, Finney, MA, Kerns, BK \& Maffei, H (2007) Modeling wildfire risk to Northern Spotted Owl (Strix occidentalis caurina) habitat in central Oregon, USA. Forest Ecology and Management, 246, 4556.

Baker, WL (2009) Fire Ecology in Rocky Mountain landscapes. Island Press, Washington D.C., USA.
Baker, WL (2012) Implications of spatially extensive historical data from surveys for restoring dry forests of Oregon's eastern Cascades. Ecosphere, 3, 23.

Beaty, RM, \& Taylor, AH (2001) Spatial and temporal variation of fire regimes in a mixed conifer forest landscape, southern Cascades, California, USA. Journal of Biogeography, 28, 955-66.

Bekker, MF., \& Taylor, AH. (2001) Gradient analysis of fire regimes in montane forests of the southern Cascade Range, Thousand Lakes Wilderness, California, USA. Plant Ecology, 155, 15-28.

Bekker, MF, \& Taylor, AH (2010) Fire disturbance, forest structure, and stand dynamics in montane forest of the southern Cascades, Thousand Lakes Wilderness, California, USA. Ecoscience, 17, 5972.

Bond, ML, Gutiérrez, RJ, Franklin, AB, LaHaye, WS, May, CA \& Seamans, ME (2002) Short-term effects of wildfires on spotted owl survival, site fidelity, mate fidelity, and reproductive success. Wildlife Society Bulletin, 30, 1022-28.

Bond, ML, Lee, DE, Siegel, RB, \& Ward Jr, JP (2009) Habitat use and selection by California Spotted Owls in a postfire landscape. Journal of Wildlife Management, 73, 1116-24.

Bond, ML, Lee, DE, Siegel, RB, \& Tingley, MW (2013) Diet and homerange size of California Spotted Owls in a burned forest. Western Birds, 44, 114-26.

Buchanan, JB, \& Irwin, LL (1998) Variation in spotted owl nest site characteristics within the eastern Cascade Mountains Province in Washington. Northwestern Naturalist, 79, 33-40.

Buchanan, JB, Irwin, LL \& McCutchen, EL (1995) Within-stand nest site selection by spotted owls in the eastern Washington Cascades. Journal of Wildlife Management, 59, 301-10.

Bull, EL, Heater, TW \& Youngblood, A (2004) Arboreal squirrel response to silvicultural treatements for dwarf mistletoe control in northeastern Oregon. Western Journal of Applied Forestry, 19, $133-41$.

Calkin, DE, Hummel, SS \& Agee, JK (2005) Modeling trade-offs between fire threat reduction and late seral forest structure. Canadian Journal of Forest Research, 35, 2562-74.

Campbell, JL, Harmon, ME \& Mitchell, SR (2012) Can fuel-reduction treatments really increase forest carbon storage in the western U.S. by reducing future fire emissions? Frontiers in Ecology and Environment, 10, 83-90.

Carey, AB (2001) Experimental manipulation of spatial heterogeneity in Douglas-fir forests: effects on squirrels. Forest Ecology and Management, 152, 13-30.

Cary, GJ, Flannigan, MD, Keane, RE, Bradstock, RA, Davies, ID, Lenihan, JM, Li, C Logan, KA \& Parsons, RA (2009) Relative importance of fuel management, ignition management and weather for area burned: evidence from landscape-fire succession models. International Journal of Wildland Fire, 18, 147-56.

Clark, DA, Anthony, RG, \& Andrews, LS (2013) Relationship between wildfire, salvage logging, and occupancy of nesting territories by Northern Spotted Owls. The Journal of Wildlife Management, 77, 672-88.

Cruz, MG, \& Alexander, ME (2010) Assessing crown fire potential in coniferous forests of western North America: a critique of current approaches and recent simulation studies. International Journal of Wildland Fire, 19, 377-98.

DellaSala, DA, \& Williams, JE (2006) The Northwest Forest Plan, a global model of forest management in contentious times. Conservation Biology, 20, 274-6.

Dugger, KM, Anthony, RM, \& Andrews, LS (2011) Transient dynamics of invasive competition: Barred owls, spotted owls, habitat, and the demons of competition present. Ecological Applications, 21, 245968.

Everett, RL, Schellhaas, D, Spurbeck, D, Ohlson, P, Keenum, D \& Anderson, T (1997) Structure of Northern Spotted Owl nest stands and their historical conditions on the eastern slope of the Pacific Northwest Cascades, USA. Forest Ecology and Management, 94, $1-14$.

Forsman, ED, Meslow, EC, \& Wight, HM (1984) Distribution and biology of the spotted owl in Oregon. Wildlife Monographs, No. 87.

Franklin, AB, Anderson, DR, Gutiérrez, RJ \& Burnham, KP (2000) Climate, habitat quality, and fitness in Northern Spotted Owl populations in northwestern California. Ecological Monographs, 70, 539-590.

Franklin, JF, \& Johnson, NK (2012) A restoration framework for federal forests in the Pacific Northwest. Journal of Forestry, 110, 429-39. 
Gaines, WL, Harrod, RJ, Dickinson, J, Lyons, AL \& Halupka K (2010) Integration of Northern Spotted Owl habitat and fuels treatments in the eastern Cascades, Washington, USA. Forest Ecology and Management, 260, 2045-52.

Gomez, D, Anthony, RG, \& Hayes, JP (2005) Influence of thinning of Douglas-fir forests on population parameters and diet of northern flying squirrels. Journal of Wildlife Management, 69, 1670-82.

Hanson CT (2013) Habitat use of Pacific fishers in a heterogeneous post-fire and unburned forest landscape on the Kern Plateau, Sierra Nevada, California. The Open Forest Science Journal, 6, 24-30.

Hanson, CT, Odion, DC, DellaSala, DA, \& Baker, WL (2009) Overestimation of fire risk in the Northern Spotted Owl recovery plan. Conservation Biology, 23, 1314-9.

Hanson, CT, Odion, DC, DellaSala, DA, \& Baker, WL (2010) Morecomprehensive recovery actions for Northern Spotted Owls in dry forests: reply to Spies et al. Conservation Biology, 24, 334-7.

Hessburg, PF, Povak, NA, \& Salter, RB (2008) Thinning and prescribed fire effects on dwarf mistletoe severity in an eastern Cascade dry forest, Washington. Forest Ecology and Management, 255, 2907-15.

Hessburg, PF, Salter, RB, \& James, KM (2007) Re-examining fire severity relations in pre-management era mixed conifer forests: inferences from landscape patterns of forest structure. Landscape Ecology, 22, $5-24$.

Hicks, LL, Stabins, HC, \& Herter, DR (1999) Designing spotted owl habitat in a managed forest Journal of Forestry, 97, 20-25.

Holloway, GL, \& Smith, WP (2011) A meta-analysis of forest age and structure effects on northern flying squirrel densities. Journal of Wildlife Management, 75, 668-74.

Hummel, S, \& Calkin, DE (2005) Costs of landscape silviculture for fire and habitat management. Forest Ecology and Management, 207, 385-404.

Hutto, RL, (2008) The ecological importance of severe wildfires: some like it hot. Ecological Applications, 18, 1827-34.

Irwin, LL, Rock, DF \& Rock, SC (2012) Habitat selection by Northern Spotted Owls, in mixed conifer forests. The Journal of Wildlife Management, 76, 200-13.

Jenness, JJ, Beier, P, \& Ganey, JL (2004) Associations between forest fire and Mexican Spotted Owls. Forest Science, 50, 765-72.

Johnson, KN, \& Franklin, JF (2009) restoration of federal forests in the pacific northwest: strategies and management implications. Unpublished Report. Oregon State University, Corvallis (available from http://www.cof.orst.edu/cof/fs/PDFs/RestorationOfFederalForestsInThePacificNorthwest.pdf, [Accessed 26 October, 2012].

King, GM (1993) Habitat Characteristics of Northern Spotted Owls in Eastern Washington. Masters Thesis. University of California, Berkeley.

LaHaye, WS, \& Gutiérrez, RJ (1999) Nest sites and nesting habitat of the Northern Spotted Owl in northwestern California. The Condor, 101, 324-30.

Lawrence, GE (1966) Ecology of vertebrate animals in relation to chaparral fire in the Sierra Nevada Foothills. Ecology, 47, 278-91.

Lee, DE, Bond, ML \& Siegel, RS (2012) Dynamics of breeding-season site occupancy of the California Spotted Owl in burned forests. The Condor, 114, 792-802.

Lee, D, \& Irwin, LL (2005) Assessing risks to spotted owls from forest thinning in fire-adapted forests of the western United States. Forest Ecology and Management, 211, 191-209.

Lehmkuhl, JF, Kennedy, M, Ford, DE, Singleton, PH, Gaines, WL, \& Lind, RL (2007) Seeing the forest for the fuel: Integrating ecological values and fuel management. Forest Ecology and Management, 259, 73-80.

Lehmkuhl, JF, Kistler, KD \& Begley, JS (2006) Bushy-tailed woodrat abundance in dry forests of eastern Washington. Journal of Mammalogy, 87, 371-9.

Manning, T, Hagar, JC, \& McComb, BC (2012) Thinning of young Douglas-fir forests decreases density of northern flying squirrels in the Oregon Cascades. Forest Ecology and Management, 264, 15124.

Meiman, S, Anthony, RG, Glenn, EM, Bayless, T, Ellingson, A, Hansen, MC, \& Smith, C (2003) Effects of commercial thinning on home range and habitat use patterns of a males Northern Spotted Owl: a case study. The Wildlife Society Bulletin, 31, 1254-62.

Meyer, MD, Kelt, DA, \& North, MP (2007) Microhabitat associations of northern flying squirrels in burned and thinned forest stands of the Sierra Nevada. American Midland Naturalist, 157, 202-11.
Miller, JD, \& Thode, AE (2007) Quantifying burn severity in a heterogeneous landscape with a relative version of the delta Normalized Burn Ratio (dNBR). Remote Sensing of Environment, 109, 66-80.

Miller, JD, Skinner CN, Safford, HD, Knapp, EE, \& Ramirez, CM (2012) Trends and causes of severity, size, and number of fires in northwestern California, USA. Ecological Applications, 22, 184203.

Moeur, M, Spies, TA, Hemstrom, M, Martin, JR, Alegria, J, Browning, J Cissel, J, Cohen, WB, Demeo, TE, Healey, S, \& Warbington, R (2005) Northwest Forest Plan-the first 10 years (1994-2003): status and trend of late-successional and old-growth forest. U.S. Forest Service General Technical Report PNW-GTR-646, Pacific Northwest Research Station, Portland, Oregon, USA.

Odion, DC, Frost, EJ, Strittholt, JR, Jiang, H, DellaSala, DA, \& Moritz, MA (2004) Patterns of fire severity and forest conditions in the western Klamath mountains, California. Conservation Biology, 18, 927-36.

Odion, DC, \& Hanson, CT (2013) Projecting impacts of fire management on a biodiversity indicator in the Sierra Nevada and Cascades, USA: the black-backed woodpecker. The Open Journal of Forest Science, 6, 14-23.

Odion, DC, Hanson, CT, Arsenault, A., Baker, WL, DellaSala, DA, Hutto, RL, Klenner, W, Moritz, MA, Sherriff, RL, Veblen, TT, \& Williams, MA (2014) Examining historical and current mixedseverity fire regimes in ponderosa pine and mixed-conifer forests of western North America. PLoS ONE, 9, e87852.

Pidgeon, AM (1995) Habitat Characteristics of Northern Spotted Owls in the Unmanaged forest of the Yakima Indian Reservation, Eastern Washington. Masters Thesis. Central Washington University, Ellensburg, Washington, USA.

Power, TM (2006) Public timber supply, market adjustments, and local economies: economic assumptions of the Northwest Forest Plan. Conservation Biology, 20, 341-50.

Ransome, DB, \& Sullivan, TP (2002) Short-term population dynamics of Glaucomys sabrinus and Tamiasciurus douglasii in commercially thinned and unthinned stands of coastal coniferous forest. Canadian Journal of Forest Research, 32, 2043-50.

Ransome, DB, Lindgren, PMF, Sullivan, DS \& Sullivan, TP (2004) Longterm responses of ecosystem components to stand thinning in young lodgepole pine forest. I. Population dynamics of northern flying squirrel and red squirrel. Forest Ecology and Management, 202, 355-67.

Raphael, MG, Hessburg, P, Kennedy, R, Lehmkuhl, J, Marcot BG, Scheller R, Singleton P, \& Spies T (2013) Assessing the compatibility of fuel treatments, wildfire risk, and conservation of northern spotted owl habitats and populations in the eastern Cascades: a multi-scale analysis. JFSP Project 09-1-08-31. United States Joint Fire Science Program, Boise, Idaho (https://www.firescience.gov/projects/09-108-31/project/09-1-08-31_final_report.pdf, [Accessed 19 June 2014].

Rhodes, JJ, \& Baker, WL (2008) Fire probability, fuel treatment effectiveness and ecological tradeoffs in western U.S. public forests. Open Forest Science Journal, 1, 1-7.

Roberts, SL (2008) The effects of fire on California Spotted Owls and their mammalian prey in the central Sierra Nevada, California. Ph.D Dissertation, University of California Davis.

Roberts, SL; van Wagtendonk, JW; Miles, AK; \& Kelt, DA (2011) Effects of fire on spotted owl site occupancy in a late-successional forest. Biological Conservation, 144, 610-9.

Roloff, GJ, Mealey, SP, \& Bailey, JD (2012) Comparative hazard assessment for protected species in a fire-prone landscape. Forest Ecology and Management, 277, 1-10.

Roloff, GJ, Mealey, SP, Clay, C, Barry, J, Yanish, C \& Neuenschwander, L (2005) A process for modeling short- and long-term risk in the southern Oregon Cascades. Forest Ecology and Management, 211, 166-90.

Scheller, RM, Spencer, WD, Rustigian-Ramosos, Syphard, AD, Ward BC, \& Strittholt, JR (2011) Using stochastic simulation to evaluate competing risks of wildfires and fuels managment on an isolated forest carnivore. Landscape Ecology, 26, 1491-504.

Seamans, ME \& Gutiérrez RJ (2007) Habitat selection in a changing environment: the relationship between habitat alteration and spotted owl territory occupancy and breeding dispersal. The Condor, 109, 566-6. 
Spies, TA, Hemstrom, MA, Youngblood, A, \& Hummel, S (2006) Conserving old-growth forest diversity in disturbance-prone landscapes. Conservation Biology, 20, 351-62.

Stephens, S L \& Ruth, LW (2005) Federal forest-fire policy in the United States. Ecological Applications, 15, 532-42.

Stephens, SL., McIver, JD, Boerner, REJ, Fettig, CJ, Fontaine, JB, Hartsough, BR, Kennedy, P, \& Schwilk, DW (2012) Effects of forest fuel reduction treatments in the United States. BioScience, $62,549-59$.

Suzuki, N \& Hayes, JP (2003) Effects of thinning on small mammals in Oregon coastal forests. Journal of Wildlife Management, 67, 35271.

Taylor, AH \& Skinner, CN (1998) Fire history and landscape dynamics in a late-successional reserve, Klamath Mountains, California, USA. Forest Ecology and Management, 111, 285-301.

Taylor, A.H. \& Skinner, C.N. 2003. Spatial patterns and controls on historical fire regimes and forest structure in the Klamath Mountains. Ecological Applications 13, 704-19.

Thomas, JW, Franklin, JF, Gordon, J \& Johnson, KN (2006) The Northwest Forest Plan: origins, components, implementation experience, and suggestions for change. Conservation Biology, 20, 77-87.

USDI (2011) Environmental assessment for pilot joe demonstration project. Medford, Oregon, USDI Bureau of Land Management.

USFS and USDI (1994) Final supplemental environmental impact statement on management of habitat for late-successional and old-growth forest related species within the range of the Northern Spotted Owl. Portland, Oregon, USDA Forest Service and USDI Bureau of Land Management.

USFS (2010) Field Instructions for the annual inventory of Washington, Oregon, and California, 2010. Portland, Oregon, USDA Forest Service, Pacific Northwest Research Station.

USFS (2011) Plumas Lassen study 2010 annual report: spotted owl module. Vallejo, California. USDA Forest Service.
USFS (2011) Proposed action for forest plan revision, Okanogan-Wenachee National Forest. Wenachee Washington, USDA Forest Service.

USFWS (2008) Final Recovery Plan for the Northern Spotted Owl (Strix occidentalis caurina). Portland, Oregon, USFWS.

USFWS (2011) Revised Recovery Plan for the Northern Spotted Owl (Strix occidentalis caurina). Portland, Oregon, USFWS.

Waters, JR, McKelvey, KS, Zabel, CJ, \& Luoma, D (2000) Northern flying squirrel mycophagy and truffle production in fir forests in northeastern California. pp. 73-97 In RF Powers Ed. Proceedings of the California Forest Soils Council Conference on Forest Soil Biology and Forest Management. GTR PSW-GTR-178. U.S. Department of Agriculture, Pacific Southwester Research Station, Albany, CA, USA.

Waters, JR \& Zabel, CJ (1995) Northern flying squirrel densities in fir forests of northeastern California. Journal of Wildlife Management, 59, 858-66.

Whittaker, RH (1960) Vegetation of the Siskiyou Mountains, Oregon and California. Ecological Monographs, 26, 1-80.

Wiens, JD (2012) Competitive Interactions and Resource Partitioning Between Northern Spotted Owls and Barred Owls in Western Oregon. Ph.D Dissertation. Oregon State University, Corvallis, OR.

Wills, R.D \& Stuart, J.D (1994) Fire history and stand development of a Douglas-fir/hardwood forest in northern California. Northwest Science, 68, 205-12.

Wilson, JS, \& Baker, PJ (1998) Mitigating fire risk to late-successional forest reserves on the east slope of the Washington Cascade Range, USA. Forest Ecology and Management, 110, 59-75.

Wilson, TM (2008) Limiting Factors for Northern Flying Squirrels (Glaucomys sabrinus) in the Pacific Northwest: a Spatio-temporal Analysis. Ph.D Dissertation Union Institute \& University, Cincinnati, p. 219.

Received: March 23, 2014

Revised: April 18, 2014

Accepted: April 18, 2014

(c) Odion et al.; Licensee Bentham Open.

This is an open access article licensed under the terms of the Creative Commons Attribution Non-Commercial License (http://creativecommons.org/ licenses/by-nc/3.0/), which permits unrestricted, non-commercial use, distribution and reproduction in any medium, provided the work is properly cited. 